\title{
Linkage of Management Decisions to Shareholder's Value: EVA Concept
}

\author{
Shrikant Panigrahi ${ }^{\mathrm{a}}$, Yuserrie Bin Zainuddin ${ }^{\mathrm{b}}$, Noor Azlinna Binti Azizan ${ }^{\mathrm{c}}$ \\ ${ }^{a}$ PhD student, University Malaysia Pahang, Kuantan 26300, Malaysia \\ ${ }^{b}$ Professor, University Malaysia Pahang, Kuantan 26300, Malaysia \\ ${ }^{c}$ Professor, University Malaysia Pahang, Kuantan 26300, Malaysia
}

\begin{abstract}
In this paper, the author investigated the influence of management decisions like capital structure, dividend policies, remunerations, credit policy decisions and investment decisions on shareholder wealth maximization. The main objective of this paper is to increase awareness and relationship between management and shareholders of the companies. To achieve the objective, portfolio theory, capital asset pricing model and modern financial theory providing evidence on the linkage between management decisions to shareholder's value. Shareholders are only concerned about the value of shares of the company and the amount of return in the form of dividend paid. Thus in order to meet the demands of the shareholders of the company, managers needs to increase their abilities and skills to overcome the organizational goals. Thus the main goal of this paper is to discuss on the role of management decisions towards increasing shareholder's wealth and meet organizational goals.
\end{abstract}

Keywords: Management Decisions, Shareholder's wealth maximization, capital asset pricing model, modern financial theory

\section{(C) 2014 Published by SSBFNET}

\section{Introduction}

Continuous innovation in the management techniques of the companies have been one of the challenges in the business environment and improve their effectiveness (De Hart and De Wet 2008). In the field of management accounting and financial management there have been number of new management concept been came into existence. One of the key concept that have been considered as superior by (Stewart 1991, Stern 1993, Berber, Pasula et al. 2012) amongst other management techniques is Economic Value Added (EVA). Shareholders are only concerned about the value of shares of the company and the amount of return in the form of dividend paid. Thus in order to meet the demands of the shareholders of the company, managers needs to increase their abilities and skills to overcome the organizational goals. Thus the main goal of this paper is to discuss on the role of management decisions towards increasing shareholder's wealth and meet

\footnotetext{
${ }^{a}$ Corresponding author: Shrikant Panigrahi, Tel: +60105196561
} 
organizational goals. One of the key aspects of management decision is in the form of incentives compensations for managers. The issue of rewarding managers in the form of cash bonuses, in the form of stock compensation or stock putting options for top management executives, or restricted stock reward affects company goals (Sigler 2011). This study aims to investigate the role of management decisions on the wealth of shareholders or investors. Management decision is proxied in this study as an control variable investigating the relationship between economic value added and shareholder's wealth.

Over the years many financial indicators have been used to measure shareholder's value. Some of these indicators are Profit after Tax (PAT), Earnings per share (EPS), Return on Assets (ROA) and Return on Equity (ROE). All these financial indicators are being strongly criticized as they are not able to measure the cost of capital owned. Appannan and Sim (2011), mentioned that Malaysia as a developing country still lack with research on dividend policy and its determinants for the listed companies. Pandey (2003), found that plantation and consumer product sectors in Malaysia are paying high dividends due to their higher surplus in cash. Thus dividend payout decisions by managers are proxied in this study for investigating enhancement of shareholder's value. Due to market imperfections, investors may exhibit floatation costs, transaction costs and taxes. Due to asymmetric information between managers and investors there arises an agency conflict that leads the organization away from its objectives (Kapoor 2011). OHARA (2011), stated that there was a need of development and implementation of EVA due to the existence of gap between financial statement and stock price. Profit and loss statement and Balance Sheet are the two important financial statement reports that are very famous in the corporate to know and evaluate the performance. Profit and loss statement shows the result of normally one year of period while Balance Sheet shows the financial position of the assets, liabilities and equity at the fiscal year end. This shows that both the statement shows the past performance of the company. But stock price is basically decided by considering the future growth of the company; no doubt the investors review the historical income and financial position of the company. As the future growth of the company is not included in the profit and loss statement and Balance Sheet statement, it is very difficult for the investors to calculate company value and stock price from these historical financial statements.

Furthermore, Minchington and Francis (2000) found three main difficulties for the implementation of new measures in practices. Firstly there is possible lack of awareness of new measures even if there are very active promotions by the management consultants. Once the measures are being selected the barrier to the implementation includes technical difficulties like establishment of cost of capital and the capital assets. There are also some of the organizational barriers like time and resistance to change; organizations may encounter cultural and political difficulties in gaining acceptance and ownership of new measures.

Thus the main purpose of financial concept in the organization is to create awareness for the shareholders to maximize its value. The alternative performance measure EVA introduced by Stern Stewert Management Services is used to facilitate the management shareholder's relationships in the organization. EVA have already been utilized by multinational companies like Sony, Coca Cola, Seimens, and General Electric as a 
performance measurement tool for management system in the quest of creating value. Thus the main objective of this paper is to understand (1) the weakness of the existing traditional accounting performance measures; (2) Study the relationship between traditional accounting performance measures and shareholder's wealth; (3) provide an understanding to the investors in relation to the financial measurement tools and stock returns used in their investment decisions; (4) assess the role of management decisions enhancing shareholder's wealth along with maximization of firm's value. This study also provides an immense scope as the relevance, utility of EVA for making economic decisions, users, investors and shareholders has not yet demonstrated this concept in this country.

\section{Theoretical Background}

Management financial decisions help to contribute and realize the value maximization strategy (Michalski 2013). Portfolio theory discusses on the credit benefits decisions given to the customers taken by management. Credit benefits enables to determine the level of accounts receivables which in turn also increases firms net working capital and managing accounts receivables. Credit policy decision taken by the managers to its customers increases firms value. Cummins (2000), discussed on the level of capital allocation decisions through the approach of modern financial theory, the capital asset pricing model (CAPM). Capital allocation is known for the determination of the firm's equity capital for each project undertaken by the firm. Allocation of overall cost of capital also contributes to increase firm's value. In an emerging concept namely, economic value added (EVA), capital allocation decisions is considered as an important management decisions for the non-financial firms.

In the past few years it has been an ultimate goal of organization to make a revolutionary change in the measurement of performance from traditional profit based measures like Earning per Share (EPS), Return on Capital Employed (ROCE), Return on Net Worth (RONW), Net Profit Margin (NPM), Operating Profit Margin (OPM), to the new modern economic value based performance measures like Market value Added (MVA), Shareholder's Value Added (SVA), Cash Value Added (CVA), Economic Value Added (EVA). From the above mentioned concepts in recognition to accounting and financial literature, Economic Value Added (EVA) has received high attention as an important tool to measure organizational performance. EVA helps the entity to focus on how to use capital and how to generate cash from it. Managers are able to care about managing assets and income and helps in bringing up balance between then through EVA.

\subsection{Concept of EVA}

With the globalization of competition and capital markets shareholder's value has been considered and focused highly by executives in the organizations. Also shareholder's value has been considered to play a vital role to measure business performance (Rappaport 1999). Rana (2011) stated in their research that increasing shareholder's value is an innovative step that reflects the value that company provides to its shareholders. It is not so easy to measure value and opportunity cost of capital that not only increase shareholder's value but also 
achieve organizational performance. Francis \& Minchington (2002) provided in their research that balance sheet based measures that provides accounting based financial information and performance of companies often measures notional profits are not real ones.

Basic formula for EVA first proposed by Stern and Stewart Corporation is:

$E V A=$ NOPAT $-($ Cost of capital $x$ Capital $)$

Where:

\author{
NOPAT $=$ Net Operating Profits after Taxes \\ Capital $=$ Capital invested by debt holders and equity holders \\ Cost of Capital $=$ Weighted average of the cost of debt and cost of equity after taxes
}

EVA concept has been applied in many companies like COCA-COLA, AT\&T, and GE etc. EVA is closely related to Net Present Value. If the increase in EVA on a year to year basis is achieved at the expense of the EVA of future projects to gain from the EVA in the current year may be more than offset by the present value of the loss of EVA from the future periods. However there are unique relationship between EVA and firm value. According to Ray (2010) where there is increase in EVA is achieved by an increase in the cost of capital, the firm value may decrease even though EVA increases.

\title{
2.2. Advantages of EVA
}

EVA is considered as superior performance measure as compared to operating profit, profit after finance items, EPS, ROI, and ROE. EVA is very simple and operatively practical. It improves profitability normally first through improved capital turnover. EVA is very suitable for bonus system. One of the major goals of EVA is to improve efficiency of managers towards their firms through an effective cost decision making. Due to EVA, managers are obliged to generate value for their shareholders or investors. Mäkeläinen \& Roztocki (1998) mentioned that EVA shows the value for the capital used or utilized and judges the efficiency. Ability to control the operations is the main concern of EVA and plays a system of good compensation management that motivates manager to generate shareholder's value. Shareholder's value is created when there is positive EVA. The fundamental notion of EVA is to use the resources (e.g. Money) to maximize return or at least pay for the cost of using the resources (Dilon and Owers 1997). It identify the restructuring signal for the company through a series of negative EVA. Managers are able to make decision due to their deeper understanding on capital and capital costs through EVA concepts and improves business performance. Overall it indicates company's performance

\subsection{Management Decision and Shareholder's Value}

Shareholder's wealth maximization has been foremost priority nowadays for the organization as the ultimate goal. The concept of Economic Value Added as a measurement of wealth creation has been used by a number 
of large corporations. Economic Value Added not only measures performance, but if implemented in an effective manner could leads to provide information for an effective decision making, increase profitability, improve corporate governance, increases management and reward system. It is important for the firms to asses managerial performance evaluation, as most of the performance of the firms is identified from its operating activities (Marius et al, 2008). Firms operating activities generates enough cash flow for satisfactory remuneration of the creditors; cover all the imposed taxes and most important increasing shareholder's wealth. Thus strategies for implementation of EVA concept taken by managers play a crucial role.

The reason on emphasizing EVA as a value based measure increasing shareholder's wealth is that it works as the shareholders wants. In conventional accounting most of organizations incurs profit, but are not able to create value for shareholders. As stated by Peter Drucker "A business operates in loss until the return profit has not greater than its cost of capital". With the help of EVA, company actions are aligned to shareholder's value. EVA is considered as a financial measure rather than accounting measure that makes manager understand easily raising managerial awareness. EVA takes away the confusion of multiple goals that vary in standards and terms influencing planning, strategic and decision making. EVA removes such confusions by considering ultimate goal of organization to improve EVA as a common focus. This attempt to monitor, compensate and communicate effectively and improves all management decision along with creating value of shareholder's investment.

Managers and shareholders believed that growth in annual earnings per share and increase in return on equity were the best measures for maximizing shareholders wealth. However more recently there has been a growing awareness that these traditional accounting measures are not reliably linked to increase the value of the company's shares. This is because earnings do not reflect changes in risk and neither inflations nor they take into account the cost of additional capital invested to finance growth (de Wet 2005, Gupta 2012).

There is a need for value to be organized in order to identify the impact on value and for their performance to individual that can help to meet organizational goals. Below figure shows the linkage between corporate objectives and categories of value drivers: 1) Intangibles 2) operating 3) Investment and 4) Financials. 


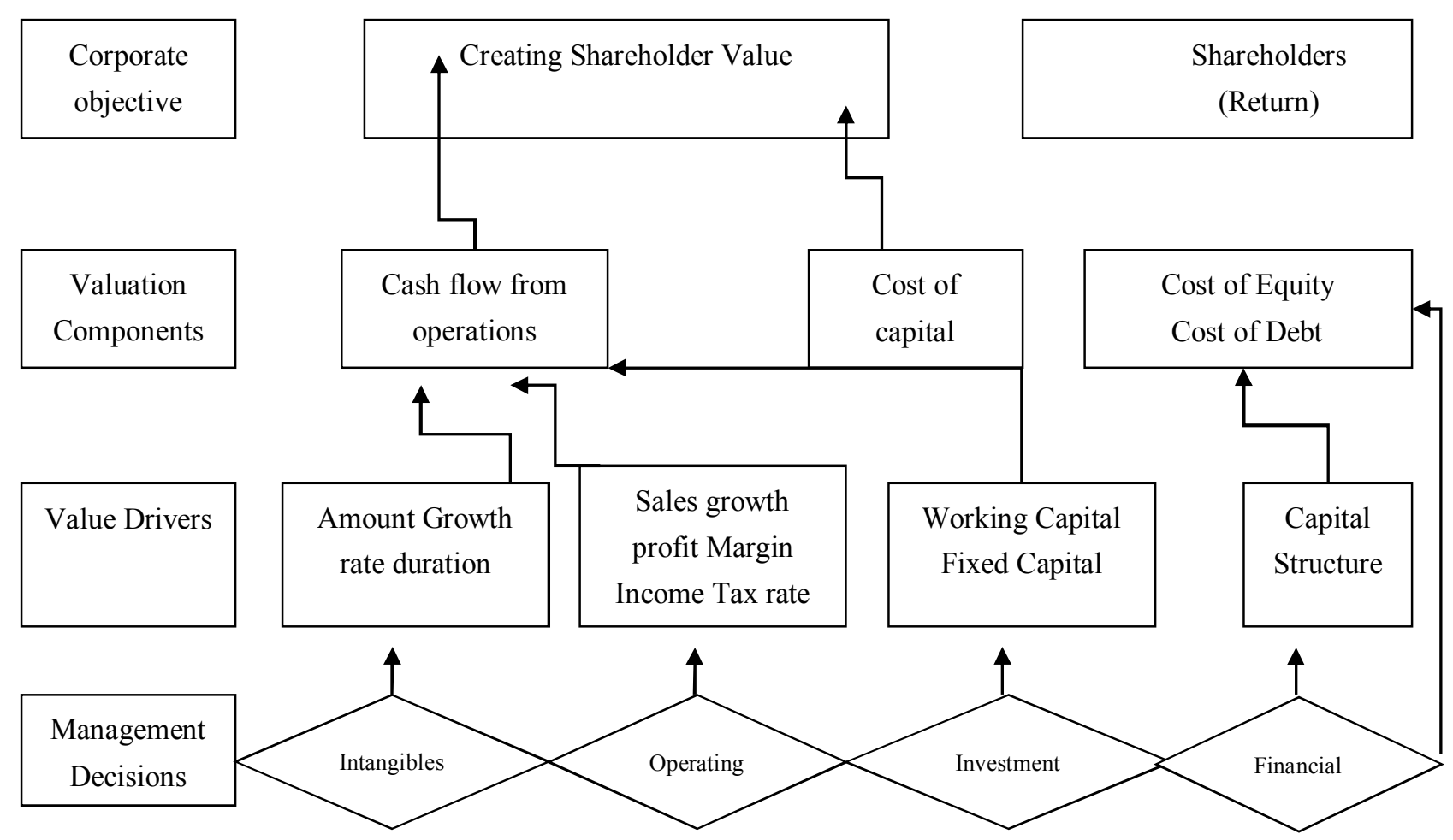

Figure 1: Value drivers for management decisions, Source: (Rappaport, 1986)

The main objective of management is to increase consistent and positive value of shareholders. Value drivers are able to determine the cash flow from operation and is influenced by operational and investment decisions taken by the management.

\subsection{Capital Structure Decisions}

Capital structure is the combination of equity, preferred and debt capital that aims to maximize the business value as a whole. Capital structure is the combination of long term finance sources that leads to lower WACC. Capital structure is expressed usually in terms of debt to equity ratio or debt to asset ratio. The total business value is determined by free cash flows of the organization, discounted at the WACC. The present value of the free cash flows over the planning horizon plus the present value of the residual value to ordinary shareholders can then be calculated by subtracting the market value of debt. The cost of capital is the combination of each source of finance. Financial sources can be categorized as own share capital, preferred share capital and debt. The word component cost means cost of a specific source of finance. Shareholders and financial institutions are known as supplier of finance requires return for the risk taken by investing in the company. Shareholders get their return in the form of dividends whereas the interest expense through debt finance is tax-deductable for the company; the cost of debt is usually cheaper than the cost of equity. 


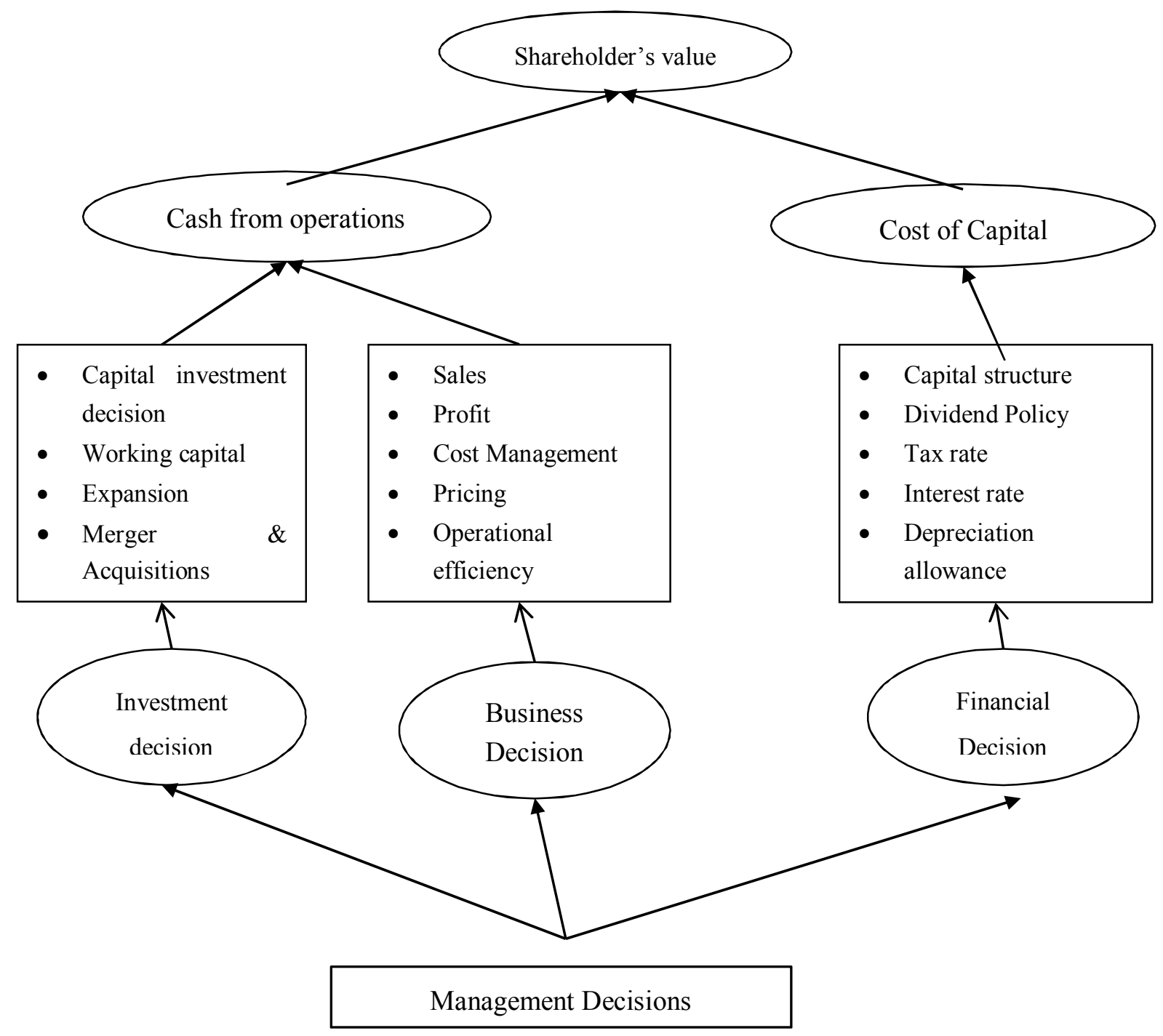

Figure 2: Managerial decision on Shareholder's value, Source:(Walters 1999)

The performance measurement tools are used for the improvement seen by the customers and results delivered to other stakeholders like shareholders. Apart from the performance of the organization there is also an important step need to be taken for formulating the direction of the strategic activities. Profitability measurements through traditional financial measures are always been misleading. Traditional financial measures are not concerned about the cost of capital incurred for making investments. Cost of equity financing is ignored focusing heavily on cost of debt financing. Thus the capital cost is not adequately provided by traditional accounting measures making its shareholders ignored through these activities.

According to Miller-Modigilani theory, it is assumed that there are no taxes, agency costs or capital structure is irrelevant. The value of the firm cannot be determined by the debt ratio. The theory also states that the cost of capital of the firm does not change with leverage and the cost of equity is increased along with increase in 
firm's leverage. The decisions for the debt financing are crucial as the failure to make the payments can lead to default due to its commitment of fixed payments.

Shareholders always expect management to generate value for them including the cost of capital. Increasing value refers to variation in the wealth of shareholders on a regular time interval. Managers must have an indepth understanding of the performance variable that drives value to the business. Organizations when act on value for shareholders also influence on things like customer satisfaction, cost, capital expenditure, operational expenditure etc.

\subsection{Investment Decisions}

Investment in the project that gives good return than the risk associated to that project is the first principle of the firms. Choosing the financing mix that matches the assets being financed with less risk maximizes shareholder's wealth (Damodaran, 2001). The comparison of accounting profit and economic profit shown by King (2009) is the cornerstone of the current transfer pricing regime. Economic rate of return is product market is equalized under competitive conditions. According to Stewart (1991) economic value added is the financial measurement tool that is able to calculate and capture economic profit for the company. The main aim of the company is to maximize their profits. Economic profit is calculated as the difference between economical and book profit. It is also defined as the difference between revenue and economic costs (book cost and opportunity costs).

\subsection{Dividend policy decisions}

Apart from value drivers, shareholder's value is also affected by the dividend policy decisions taken by the management. Dividend policy has been an emerging issue in the financial literature. Dividends are usually defined as the distribution of earnings among the shareholders of the firms on the basis of their ownership (Kapoor 2011).

Dividend payout is usually calculated as:

Dividend Payout ratio $=\underline{\text { Yearly dividend per share }}$

\section{Earnings per share}

\section{$=\quad$ Dividends}

Net income

Market price of the stock represents wealth of shareholders also presenting the decision of investing, financial and dividend distribution. Reddy and Rath (2005), investigated the behavior of dividends in the Indian firms and found that not all the firms paid regular dividends. All the firms were having different patterns to pay dividend. According to the approach by two noble winners Miller and Modigiliani (M\&M) the dividend policy does not affect the shareholder's value. The net dividend payout was the difference between earnings and 
investment also considered as residual. This findings were based on assumptions that: Information disclosed to investors are free and is available to all the investors, no tax distortion exists, non-existence of floatation and transportation costs, and non-agency cost exists (Aivazian, Booth et al. 2003).

Many researchers discussed many models in order to identify factors that influence dividend decisions from country to country. It has been an challenging issues for the identification of driver variables of dividend payout ratio in an emerging market. Issa (2012) investigated the relationship between dividend payout ratio with profitability, size, growth, opportunities, and market to book value taking 248 Malaysian firms listed in Kuala Lumpur Stock Exchange and found that return of asset, return on equity have high influence on dividend payout ratio.

Appannan and Sim (2011) examined the impact of dividend payout policy decision on Malaysian companies found that dividend payout decision like profit after tax have high influence on dividend per share. The study also confirmed that debt equity ratio and past dividend per share are major determinant for dividend payment.

\section{Previous Researches on EVA}

Tong, Yao et al. (2010), build a performance evaluation system based on Economic Value Added and Balanced Scorecard for logistics enterprises empirically and found that EVA gets significantly positive Kendall's correlation with strategic objective whose proxy is corporate value.

Wang and Fan (2010), presented performance model based on EVA method that focus on value creation attending comprehensive measurement of service oriented enterprises. The result showed that service center of issuing has a negative EVA although its profit is positive.

Sharma \& Kumar (2010) presented a narrative literature review of published papers on EVA from 1994 to 2008. They found that studies that have been conducted in advanced economy have largely found to be supporting EVA as compared to less developing economies.

Pratiwi (2008) examined the relationship between Economic value added and Market value added with reported earnings. The study found strong evidence on the relationship between EVA and MVA with reported earnings. MVA was found more significant correlations with reported earnings as compared to EVA.

Taufil et al (2008) compared value based measures with traditional / conventional performance measurement accounting tools and found that EVA is superior to ROE \& ROA in Banks Stock Returns.

Bhattacharyya \& Phani (2004) examined whether EVA is a superior performance measure for corporate reporting and internal governance. They found that EVA not able to provide additional information to the investors, but motivate and educate employees by creating shareholder's value. They also reported that dangerous trend of reporting through EVA may mislead the investors.

Grant (2003) conceptualized the concept of EVA to determine the value of stocks. The main objective of this research was to (1) estimate EVA with other accounting measures adjustments, (2) Capitalize economic profit 
to determine company's NPV (3) to estimate future EVA and its current market value added using published financial reports. This study applied quantitative technique i.e. linear and non-linear regression in order to find the most attractive companies in the capital market. Finally it was concluded that EVA is an approach of looking at the firm's real profitability.

\section{Methodology}

The current study is based on the secondary data covering a period of 7 years ranging from 2005-2006 to 2011-2012. The purpose of considering long time period for the investigation of the study is to decrease instability and cycles of business that might affect the results of the study.

Since construction companies in Malaysia are considered as one of the major economic sector, the author had an interest in the construction industry to recognize as a basic. The sample covers construction companies that are listed in Kuala Lumpur stock exchange. The firms in the population were selected based on the following criteria:

1. Construction companies that have been listed on Kuala Lumpur stock exchange in or before 2006.

2. They must be existed in KLSE till the financial year 2012.

3. They must have positive values for average operating income during the study period.

The firms must have ability towards profitable relatively, furthermore, multinational companies, assembling companies that are not based on infrastructure, companies comes under sick industrial companies were excluded in order to maintain comparability and consistency.

On the other hand, the construction industry is one of the core industries in the Malaysian economy and this industry is recognized as a basic mother industry. Therefore, any achievement in this area is extendable in other industries.

To meet the objective of the study the analysis is divided into the following sections:

1. The analysis that indicates position of shareholder's value creation in Malaysian construction companies;

2. The analysis about economic value added for creation of shareholder's value

3. Analyze the relationship between economic measures and traditional measures in addition to management decisions as performance measurement tools for the creation of shareholder's value;

In order to achieve the aim of the study the researcher had utilized trend analysis into the three sections: In the trend analysis the researcher followed the trend of the variables such as Earnings per share (EPS), return on net worth (RONW), return on capital employed (ROCE), net profit margin (NPM), operating profit margin (OPM), return on investment (ROI), economic value added (EVA), shareholder's value (SV), management investment decisions and management dividend decisions in construction companies of Malaysia. 
Calculation of figures for the formula of the variables has been performed and the data were compared with figures, graphs and trends and the growth rate of the mentioned variables. In order to find the relationship between the utilized variables Pearson correlation between the variables were examined. In order to fulfill the purpose of the study, Microsoft Excel and SPSS statistical software was taken into consideration.

Furthermore, multivariate analysis was also conducted in order to identify the influence on the measurement tools considered for the research on the enhancement of shareholder's value.

\section{Conclusions}

Accounting measures like EPS, earning growths, ROE, ROA dividends has been criticized with intensity over time. Measures of corporate performance are been mislead by Earnings, earnings per share and earnings growth. The most important criticism causes earnings to diverse from cash flows and lead to a general amount invested in the company. Investors are more interest on company's ability to generate future cash flows including risk associated with the projects undertaken to generate them instead of just profits. Due to inadequacy of accounting measures new reliable indicators is a top priority for researchers, managers and investors.

The Economic profit model calculates the actual or economic profit after taking into account the full cost of all sources of capital used. It uses the WACC to know capital change and subtract it from the profit before interest and tax. This rises to an important accounting correction of the accounting profit not taking into account opportunity cost of equity capital used.

\section{References}

Aivazian, V., L. Booth and S. Cleary (2003). Dividend policy and the organization of capital markets. Journal of Multinational Financial Management 13(2): 101-121.

Appannan, S. and L. W. Sim (2011). A Study on Leading Determinants of Dividend Policy in Malaysia Listed Companies for Food Industry Under Consumer Product Sector. 2 nd International Conference on Business and Economic Research.

Berber, N., M. Pasula and M. Radošević (2012). Economic Value Added In Function Of Determining Incentive Compensation Systems. Engineering Economics, 23(4), 414-424

Bhattacharyya, A. and B. Phani (2004). "Economic Value Added-A General Perspective." Available at SSRN 545444. Cummins, J. D. (2000). Allocation of capital in the insurance industry. Risk Management and Insurance Review 3(1): 7-27.

De Hart, F. and J. De Wet (2008). EVA and Innovations in Decision-Making and Financial Management. Available at SSRN 1656346.

de Wet, J. H. (2005). EVA versus traditional accounting measures of performance as drivers of shareholder value-A comparative analysis. Meditari Accountancy Research 13(2): 1-16.

Dilon, R. and J. Owers (1997). EVA as a financial metric: attributes, utilization ...Financial Practice \& Education 7(1): 32-40. 
Francis, G. and C. Minchington (2002). Regulating Shareholder Value: A Case Study of the Introduction of Valuebased Measures in a Water Company. British Journal of Management 13(3): 233-247.

Gupta, S. (2012). Performance Measurement: A Comparative Study of EVA and Traditional Performance Measurement Techniques: A Case Study of Steel and Petrochemicals Industry in India, GRIN Verlag.

Issa, A. I. (2012). The Determinants of Dividend Policy: Evidence from Malaysian Firms, Universiti Utara Malaysia.

Kapoor, S. (2011). Impact of dividend policy on shareholders' value: a study of Indian firms.

King, E. (2009). Economic vs. Accounting Profit Rates. Transfer Pricing and Corporate Taxation, Springer: 7-10.

Mäkeläinen, E. and N. Roztocki (1998). Economic Value Added (EVA) for small business. Retrieved March 22: 2007.

Michalski, G. (2013). Portfolio management approach in trade credit decision making. arXiv preprint arXiv: 1301.3823 .

Minchington, C. and G. Francis (2000). Divisional performance measures: EVAR as a proxy for shareholder wealth. International Journal of Business Performance Management 2(1): 98-108.

OHARA, K. (2011). "Importance Of Economic Value Added (EVA) In Japan." http://rcube.ritsumei.ac.jp/handle/10367/2625

Pandey, I. M. (2003). Corporate dividend policy and behaviour: the Malaysian evidence. Asian Academy of Management Journal 8(1): 17-32.

PRATIWI, P. W. (2008). The Relationship Between Economic Value Added (EVA) and Market Value Added (MVA) with Reported Earnings: An Empirical Research of 40 Listed Companies in Indonesia Stock Exchange for The Year 2004-2007, BINUS.

Rana, A. S. (2011). Shareholder Value Creation in the Automobile Industry in India, Saurashtra University.

Rappaport, A. (1999). Creating shareholder value: a guide for managers and investors, Free press.

Ray, K. G. (2010). Mergers and Acquisitions, PHI Learning Pvt. Ltd.

Reddy, Y. S. and S. Rath (2005). Disappearing Dividends in Emerging Markets?: Evidence from India. Emerging Markets Finance and Trade 41(6): 58-82.

Sharma, A. K. and S. Kumar (2010). Economic value added (EVA)-literature review and relevant issues. International Journal of Economics and Finance 2(2): P200.

Sigler, K. J. (2011). CEO Compensation and Company Performance. Business and Economic Journal 2011: 1-8.

Stern, J. (1993). Value and people management.Corporate Finance 104: 35-37.

Stewart, G. B. (1991). The quest for value, HarperCollins.

Taufil, H., H. Isnurhadi and M. Widiyanti (2008). The influence of traditional accounting and Economic Value Added approaches on stock returns of banks listed on Jakarta Stock Exchange (JSX). 10th MFA Annual Conference on Strengthening Malaysia's Position as a Vibrant, Innovative and Competitive Financial Hub.

Tong, Y., Y. Yao and X. Xiong (2010). Performance evaluation of logistics enterprises based on Economic Value Added and Balanced Scorecard. Logistics Systems and Intelligent Management, 2010 International Conference on, IEEE.

Walters, D. (1999). The implications of shareholder value planning and management for logistics decision making. International Journal of Physical Distribution \& Logistics Management 29(4): 240-258.

Wang, W. and Y. Fan (2010). Research on EVA Based Performance Measurement in Service Oriented Enterprise. Information Engineering (ICIE), 2010 WASE International Conference on, IEEE. 